\title{
Do we need a change in transfusion strategy in patients with subarachnoidal hemorrage?
}

\author{
S Valles Angulo*, MP Gracia Arnillas, I Dot Jordana, E Cuadrado Godia, A Ois Santiago, F Vasco Castaño, \\ R Muñoz Bermudez, M Samper Sanchez, E Vivas Diaz, G Villalba Martinez
}

From ESICM LIVES 2015

Berlin, Germany. 3-7 October 2015

\section{Objective}

To assay at what hemoglobin ( $\mathrm{Hb}$ ) levels patients recieved transfusion support, and the impact that this may have in prognosis and possible adverse effects in patients admitted with aneurismatic subarachnoidal hemorrage.

\section{Methods}

This is a retrospective observational study, including all patients admitted in our hospital diagnosed of not-traumatic $\mathrm{SAH}$, both in the Intensive Care Unit and in Stroke Unit, between 2007 and 2014. Demographics, cardiovascular risk factors, neurological deficit, GCS, Hunt \& Hess and Fisher scales, bleeding localization, aneurysm, incidence of complications (hydrocephalus, intracraneal hipertension, stroke, vasospasm), treatment (surgical or endovascular) as well as mortality were collected. We analyzed hemoglobin levels during the admittance, dividing the patients in 3 categories: $\mathrm{Hb}<7 \mathrm{~g} / \mathrm{dl}$, $\mathrm{Hb} 7-9 \mathrm{~g} / \mathrm{dl}$ and $\mathrm{Hb}>9 \mathrm{~g} / \mathrm{dl}$. In each one of these groups we collected data about transfusion, vasospasm, GOS at 1 month, and ranking at 3 months and one year.

\section{Results}

319 patients were included, 189 male $(60 \%), 62 \%$ of them smoked and $41 \%$ had high blood pressure (HBP). Clinically, $24 \%$ of patients at admittance had neurological deficit and 49\% loss of consciousness, with GCS $<7$ in $24 \%$ of them. 23 ' $5 \%$ had level III in Fisher scale and $56 \%$ were Fisher IV. Arteriography was performed in $90 \%$ of the patients included. Endovascular treatment was done in $52 \%$ versus $13 \%$ that needed surgical treatment. As complications during admittance, patients developed vasospasm in $35 \%$ of the cases $(27 \%$ before
7 days) and stroke $23 \%$ of them. Intracranial hypertension was diagnosed in $38 \%$, and global mortality the first week was $12 \%$. About 1'6\% of patients included had hemoglobin levels $<7 \mathrm{~g} / \mathrm{dl}$, and all of them recieved transfusion support; $80 \%$ had stable levels of $\mathrm{Hb}$ above $9 \mathrm{~g} / \mathrm{dl}$ and they were not transfused in any case. 18 '2\% had levels between 7 and $9 \mathrm{~g} / \mathrm{dl}$, of whom $48 \%$ recieved transfusion support. No statistically significant differences were observed when comparing patients transfused with $\mathrm{Hb}$ between 7-9 g/dl, with the group who did not recieved transfusion with same levels of $\mathrm{Hb}$, in terms of vasospasm incidence ( $41 \%$ vs $48 \%$ ), GOS at 1 month and Rankin at 3 months and 1 year.

\section{Conclusions}

Patients diagnosed of aneurysmatic SAH with hemoglobin levels between 7 and $9 \mathrm{~g} / \mathrm{dl}$, who are given transfusion support with red blood cells, seem to have no benefit in terms of complications and prognosis, when compared with the ones not transfused.

Published: 1 October 2015

doi:10.1186/2197-425X-3-S1-A772

Cite this article as: Valles Angulo et al: Do we need a change in transfusion strategy in patients with subarachnoidal hemorrage? Intensive Care Medicine Experimental 2015 3(Suppl 1):A772. 